\title{
Positive psychology and tourist well-being: A systematic literature review
}

\begin{abstract}
This paper examines the current state of research on well-being from tourism from the lens of positive psychology. A systematic review of 82 peer-reviewed articles published in English-language tourism journals indicate that tourist well-being is predominantly examined as a consequence of travel, rather than linked to tourism marketing and management. This study presents a conceptual framework of the antecedents, episodes and consequences of tourist well-being. Practically, results suggest strategies on how well-being can be used to generate better outcomes for tourism marketers and managers. By mapping what is known in the intersection between positive psychology and tourist well-being, this study identifies existing gaps and opportunities for future research in this area.
\end{abstract}

Keywords: positive psychology, tourist well-being, tourism marketing and management, systematic literature review

\section{Introduction}

Nearly a decade ago, Seligman and Csikszentmihalyi (2000) called for the development of a new science of positive psychology involving the study of human flourishing, happiness, excellence and optimal human functioning. In the tourism literature, an increasing number of studies have linked travel and tourist experiences to positive psychological outcomes and wellbeing (Coghlan, 2015; Filep, 2009; Filep \& Deery, 2010; Filep \& Laing, 2018; Filep, Macnaughton, \& Glover, 2017; Filo \& Coghlan, 2016). For example, it has been reported that people are happier during their holiday than at home (Filep, 2008b) and holidays are perceived as an escape from daily responsibilities at work (Pearce, 2009). Tourists also report higher 
levels of well-being in comparison to non-tourists (Gilbert \& Abdullah, 2004), and holidays improve the happiness and well-being for disadvantaged groups (McCabe and Johnson, 2013). These examples confirm positive psychological concepts are applicable and useful in tourism research.

However, despite the growing interest and research on positive psychology and tourist well-being, research in this area is fragmented, with little agreement on theoretical frameworks applied, methodologies used, and wide variation on where the research was carried out and whom the research samples were. Also, few studies examine if and how tourist well-being can be utilised in practice as a marketing strategy to generate business for tourism operators. A systematic literature review of research on tourist well-being from the lens of positive psychology was conducted to address these gaps. This is the first systematic review of tourist well-being studies since the introduction of positive psychology to tourism research in 2007 (Wu \& Pearce, 2014; Nawijn, 2015). This paper has two main aims (as shown in Figure 1). Firstly, to present a conceptual framework on the implications of tourist well-being on tourism marketing and management and, secondly to identify future directions for research. This review provides a timely and useful review of scientific progress of positive psychology in tourist well-being studies.

--- About insert Figure 1 here please---

\section{Systematic quantitative literature review method}

A literature review may use methods such as meta-analysis and traditional narrative reviews (Green, Johnson, \& Adams, 2006). A meta-analysis involves statistical analysis of findings from similar prior research (Mays, Pope, \& Popay, 2005), whilst narrative reviews, although more common in the academic literature, are subjective and potentially biased due to the 
reliance on the expertise of the author(s) (Petticrew, 2001). This study opted for a systematic literature review, as the main aim of this study was to map the current state of knowledge in the intersection between positive psychology and tourist well-being studies.

A systematic quantitative literature review (Pickering \& Byrne, 2014) is systematic because the methods used to select papers and survey the literature are explicit, reproducible and comprehensive. This study considers two main reasons for conducting a systematic quantitative literature review. Firstly, systematic quantitative literature reviews are useful in exploring new and emerging trends within disciplines (Pickering \& Byrne, 2014) and, secondly, a systematic and quantitative method allows boundaries to be mapped on what is known, and thus identifies gaps on what is yet to be known (Pickering, Grignon, Steven, Guitart, \& Byrne, 2015). Systematic quantitative literature reviews have also been applied in doctoral research such as risk and gender research (Yang, Khoo-Lattimore, \& Arcodia, 2017), virtual and augmented reality in tourism research (Yung \& Khoo-Lattimore, 2017) and air transport and tourism (Spasojevic, Lohmann \& Scott, 2018).

\subsection{Planning and conducting the review}

The systematic review process used in this study was adopted by Tranfield, Denyer, and Smart (2003) and Pickering and Byrne (2014). Firstly, a research question was formulated to guide the overall review (De Menezes \& Kelliher, 2011). In this study, the question the review addresses are: "What are the existing theoretical and methodological frameworks applied from positive psychology to the study of tourist well-being in tourism research, and how have these been applied to marketing and management?" Following the establishment of the research question and aims (refer Figure 1), the review process began with the scoping of studies to clarify the theoretical context of the subject area. Seminal papers (see Table 1) in the field of positive psychology and tourism research were revi ewed (Filep, 2008; Pearce, 2009; 
Moscardo, 2009, Filep \& Deery, 2010; Nawijn Peters, 2010; Voigt, Howat \& Brown, 2010; Nawijn, 2011; Nawijn, 2015; Filep, 2016 and Nawijn \& Filep, 2016). Two academic experts specializing in positive psychology and tourist well-being studies were consulted on the selection and significance of these studies. This initial investigation assisted in the identification of keywords for the subsequent stages.

--- About insert Table 1 here please---

In order to minimize potential bias, this study used search terms in different databases and applied specific inclusion and exclusion criteria (Tranfield, Denyer \& Smart, 2003; Pickering \& Byrne, 2014). The following section describes the searching, screening, and extraction/synthesis stages of the review, which were carried out by the first author. It is worthy to note that the co-authors in this study were consulted throughout the systematic review process.

\subsection{Searching}

An initial scoping of the literature, including the consultation of seminal papers with two academic experts assisted in the identification of keywords. The search terms "positive psychology, well-being or happiness" and "tourism, travel, tourist or tourist experiences" were used as these were common keywords from the seminal papers and used in recent tourism studies, which applied positive psychological theories (Coghlan, 2015; Filep et al., 2017; Filo \& Coghlan, 2016; Glover \& Filep, 2016; Nawijn \& Filep, 2016; Smith \& Diekmann, 2017). According to Picking \& Byrne (2014), the keywords used in a systematic literature review should identify as much of the relevant literature as possible, but not extend too far into unrelated fields. 
The literature search was firstly conducted in the Scopus academic database, followed by four additional databases: EBSCO Host, Elsevier, ProQuest, and Emerald. These databases are those used in similar studies (Yang, Khoo-Lattimore, \& Arcodia, 2017; (Yung \& KhooLattimore, 2017). The electronic databases were searched for articles whose titles and/or abstracts contained at least one of the search terms from two themes, by linking the strings (see Table 2) with the Boolean operator (AND).

--- About insert Table 2 here please---

\subsection{Screening}

As of December 2018, the literature search against the four databases yielded 253 records. These records were exported to the Endnote software for data management. There were 32 duplicate references, which were removed, and the remaining 221 records were screened against the selection criteria. The screening of titles and abstracts at this stage was informed by the inclusion and exclusion criteria (see Table 3) adapted from Watson, Wilson and Macdonald (2018). These records were screened to identify original research articles published in the English-language peer-reviewed journals, with the application of positive psychological concepts and theories within the tourism sector.

--- About insert Table 3 here please---

The screening process generated 92 records. The full texts for these 92 records were further reviewed for eligibility and inclusion in the final analysis. Ten studies were discarded at this stage due to the research context and focus. For example, the study by Yau and Packer (2002) was excluded because the study did not have a tourism or travel focus although it explored the 
meaning, values and benefits of T'ai Chi practice. Similarly, studies by Williams, Childers, and Kemp (2013) and Mackenzie, Son, and Eitel (2018) were excluded as the context was within a classroom and education environment respectively. The study by Lee and Kyle (2013) measured emotions within festival contexts but lacked reference to tourist well-being. Likewise, the study by Io (2017) examined positive emotions and satisfaction within the casino context with no reference to tourist well-being. The studies by Lee and Bai (2014), Breiby and Slåtten (2015), Lin and Kuo (2016) and Organ, Koenig-Lewis, Palmer, and Probert (2015) were also excluded as they focused on outcomes of emotions on behavioural change, word-ofmouth and revisit intention. The study by Torres, Wei and Hua (2017) was excluded because the focus was on how tourists recalled positive emotions with no reference on how positive emotions may have influenced tourist well-being during vacations. The final database consisted of 82 peer-reviewed articles. Figure 2 presents a flowchart of studies screened and excluded at different stages of the review.

--- About insert Figure 2 here please---

\subsection{Extraction and synthesis}

This study used inductive content analysis to analyse the 82 peer-reviewed articles because there was insufficient former knowledge about the phenomenon and existing knowledge was fragmented (Elos \& Kyngas, 2008). Microsoft Excel software was used to create a summary table in which the bibliographic details of the 82 peer-reviewed articles were tabulated. The authors coded categories by information on the author (i.e. affiliation, institution, and country), publication information (i.e. year, article title, and journal title), article type (empirical vs nonempirical), theoretical frameworks applied, methodological frameworks (quantitative, qualitative, and mixed methods), research context and characteristics of research samples. 
It is common for systematic literature reviews to employ qualitative data-analysis software such as NVivo or Leximancer, however, this study opted for quantitative synthesis and interpretation as this method has been deemed a significant technique to a successful literature review (Bandara, Futmueller, Gorbacheva, Miskon \& Beekhuyzen, 2015).

\section{Findings}

Based on the first-author affiliation, the selected papers were published across 19 different countries (see Table 4). Most articles were published in Australia (9\%), USA (8\%), Netherlands (7\%), New Zealand (5\%) and United Kingdom (4\%). The top three authors in the intersection of research between positive psychology and tourist well-being studies were Sebastian Filep, Philip Pearce and Jerome Nawijn.

--- About insert Table 4 here please---

The 82 peer-reviewed articles included in the systematic review are presented in a cumulative frequency distribution chart (see Figure 3). The first published article was written by Filep (2008) who applied models from the field of positive psychology in conceptualising and appraising tourist satisfaction. To identify trends in the volume of research publications covered by this review, the period 2008 - 2018 was divided into four periods (three of 3 years and one of 2 years). There was a substantial increase in publications in the second period (2011 - 2013) with an increase of 13 papers. Whilst the third period (2014- 2016) showed a slight decline in publications, the fourth period $(2017$ - 2018) showed an extensive acceleration in the number of publications of positive psychology in tourism research. The 82 peer-reviewed articles were published in 30 different journals (see Table 5). Most articles were published in 
the top-ranking tourism journals such as the Annals of Tourism Research (23\%), Tourism Management (13\%) and the Journal of Hospitality and Tourism Research (7\%).

--- About insert Figure 3 and Table 5 here please---

\subsection{Theoretical frameworks}

From the 82 peer-reviewed articles, there were 28 theories or models, which were either cited or applied (see Table 6). Not all theories were drawn from the positive psychology discipline. The positive psychology theories which were applied were the broaden and build theory of positive emotions, flow theory, PERMA model, mindfulness theory, subjective well-being model, savouring, effort recovery theory, self-determination theory and top-down and bottomup theories of well-being. The main variables, which were measured in current research, were happiness, well-being, emotions and life satisfaction (see Table 7).

--- About insert Table 6 and 7 here please---

The broaden and build theory of positive emotions (Fredrickson, 2004a) was the most commonly applied positive psychological theory. The broaden and build theory of positive emotions claims that certain positive emotions broaden people's momentary thought-action repertoires and build their enduring physical, social and psychological resources. Empirical research found that positive emotions help people to cope with adversity (Fredrickson, 2004b; Miao et al., 2013; Mitas, Yarnal, \& Chick, 2012; Tugade \& Fredrickson, 2004), and contributes to the improvement of cardiovascular activation following negative emotions (Fredrickson, Tugade, Waugh, \& Larkin, 2003). Within a tourism context, Pearce (2009) suggested the application of the broaden and build theory in highlighting the ratio of positive to negative 
emotions, and the consequences of positive emotions for traveller learning and understanding future behaviour. Previous studies have examined the broaden and build processes in older women participating in the Red Hat Society (Mitas, Qian, Yarnal, \& Kerstetter, 2011), converting emotional reactions felt during a tourist experience to shape poverty alleviation programmes into useful behaviours (Pearce, 2012) and how positive emotions can be maintained and extended after a holiday (Filep et al., 2013).

The flow theory (Csikszentmihalyi, 1975) was also applied within the context of whitewater rafting (Wu \& Liang, 2011), online shopping in travel (Nusair \& Parsa, 2011), adventure tourism (Mackenzie et al., 2018), surfing activities (Cheng \& Lu, 2015) and mountain holidays (Frochot et al., 2017). PERMA is an acronym for a model of well-being comprising of five building blocks of well-being and happiness: positive emotions, engagement, relationships, meaning and achievement (Seligman, 2004). Three empirical studies applied the PERMA model which highlighted eudaimonic aspects of tourism (Filep \& Pearce, 2013). The exploratory study by Dillette, Douglas and Andrzejewski (2018) revealed that the PERMA model of well-being could lead to greater levels of holistic wellness through yoga retreat experiences. Laing and Frost (2017) found that four out of the five dimensions of the PERMA model triggered well-being in the work of female travel writers in Italy. These four dimensions were positive emotions, relationships, meaning and achievement. Kalaiya and Kumar (2018) found that the PERMA model of well-being was capable in explaining tourists' decision to spend more time in one particular place, the choice of a number of places visited during one trip and the overall satisfaction derived from his or her travel.

\subsection{Methodological frameworks}

From the 82 peer-reviewed articles, 63 of these articles were empirical papers and the remaining 19 were non-empirical or conceptual papers (see Table 8). From the 63 empirical 
papers, 27 papers utilized a quantitative approach and 27 papers utilized a qualitative approach with the remaining nine using mixed methods. As interviews comprised of the main qualitative research method, thematic analysis was the most commonly used technique for data analysis (see Figure 4). However, there was a wider variety of data analysis techniques applied in quantitative research methods (see Figure 5).

--- About insert Table 8, Figure 4 and Figure 5 here please---

There were also four longitudinal studies, however, three out of the four studies focused on Dutch citizens in Netherlands. For example, the study by Nawijn (2011) included 3,650 Dutch citizens who reported their leisure travel every 3 months over 2 years and rated their happiness at the end of each year. Nawijn, Mitas, Lin and Kerstetter (2013) recorded the emotions of 39 Dutch participants across 14 or more days. A more recent study by de Bloom, Nawijn, Geurts, Kinnunen and Korpela (2017) carried out a five-week longitudinal field study, which followed 24 Dutch workers during free events after work, a free weekend at home and on a free weekend of domestic travel. The study by Frochot, Elliot and Kreziak (2017) was carried out in France during a five-day tourist stay in a mountain resort to analyse flow and immersion. A longitudinal design allows the separation of cause and effect and is thus a suitable method to assess the changes in well-being over time.

The majority of studies adopted scales and measurements from previous studies (see Table 9). The scales that were drawn from positive psychology and significantly applied throughout the studies included the Satisfaction with Life Scale (Diener, 1984), Positive and Negative Affect Scale (PANAS) (Watson, Clark \& Tellegen, 1988), the Subjective Happiness Scale (Lyubomirsky, King \& Diener, 2005) and the Modified Differential Emotions Scale (Fredrickson \& Branigan, 2005). 
--- About insert Table 9 please---

\subsection{Research samples}

In terms of gender distribution, there were $4.9 \%$ more females than males. The majority of studies included respondents whose ages were between 18-35 years (see Table 10). Whilst there were 11 studies that included respondents whose ages were above 60 years, there were only two studies, which specifically focused on elderly people. For example, the study by Morgan, Pritchard and Sedgley (2015) investigated the well-being value of social tourism on economically disadvantaged older people and the study by Moal-Ulvoas (2017) examined the potential of travel to generate self-transcendent positive emotions and contribute to the spirituality of senior travellers.

--- About insert Table 10 here please---

The research samples from the 61 empirical studies were also concentrated in primarily developed countries (Australia, United States of America, United Kingdom, and Netherlands) and western cultures (see Figure 6). There were only four studies which focused on Chinese travellers (Chen, Lehto \& Cai, 2013; Filep, Cao, Jiang \& DeLacy, 2013; Li \& Chan, 2017; Lin, Chen \& Filieri, 2017). However, two of these studies used Chinese samples in Australia (Filep et al., 2013) and the USA (Li \& Chan, 2017). The remaining two studies used Chinese samples within China (Chen et al., 2013; Lin et al., 2017). The largest sample size for the quantitative study was by Nawijn (2011) with 3650 Dutch travellers. This is in contrast to the sample size for the qualitative study by Houge, Hodge and Boyes (2013) with only five travellers. 
--- About insert Figure 6 here please---

The context of these peer-reviewed articles were focused on the tourists' perspective, in terms of their happiness, positive emotions, and well-being and life satisfaction. For example, holiday trips were found to have an effect on visitor happiness (Nawijn \& Peeters, 2010; Nawijn, Marchand, Veenhoven \& Vingerhoets, 2010), vacations induced more positive than negative emotions (Nawijn et al., 2013), and the health and well-being of tourists increased during longterm vacations (de Bloom, Geurts \& Kompier, 2013). There was minimal focus on residents or host communities or tourism workers.

\section{Discussion}

One of the aims of this study was to identify future directions for research in the intersection between positive psychology and tourist well-being studies. To achieve this aim, this study carried out a systematic review of 82 peer-reviewed articles on the intersection between positive psychology and tourist well-being studies. The major findings from the 82 peerreviewed articles showed that:

1. Existing research did not clearly articulate a theoretical base and a limited number of positive psychological theories have been applied to tourist well-being studies within tourism research;

2. The positive psychological variables continue to revolve around happiness and well-being;

3. There is a balance in the application of qualitative and quantitative methodological techniques;

4. The research focus is examined predominantly from tourists' perspective; and,

5. The geographic settings of research were predominantly in developed countries with research samples from western cultures. A detailed discussion of the findings follows. 


\subsection{Theoretical frameworks}

This review found that the major positive psychological variables, which were measured, included happiness, well-being, emotions and life satisfaction. Positive psychology is the study of happiness, well-being, life satisfaction and quality of life (Seligman \& Csikszentmihalyi, 2000) which justifies the inclusion of these major variables in existing research between positive psychology and tourist well-being studies. However, it should be noted that one of the major challenges for tourism research on happiness, well-being and quality of life is the difficulty in clearly defining and differentiating between these terms and concepts as scholars often use the concepts of happiness, well-being, quality of life and life satisfaction interchangeably (Filep \& Deery, 2010; Pearce, 2009). The review also indicates that concepts of happiness and well-being continue to represent significant topics of interest in tourism and hospitability research for both academics and practitioners. Significantly, academic literature has responded to recent tourism and travel trends which suggest that the market for holidays that focuses on well-being is growing exponentially.

Although positive psychology covers different concepts; well-being (both hedonic and eudaimonic) are central concepts of the positive psychology discipline. This is evident when examining the origins of positive psychology which can be traced back to Ancient Greek and European philosophy (Smith \& Diekmann, 2017). The major philosophical orientations were originally studied from hedonic and eudaimonic well-being philosophical traditions. The hedonic view is based on the 4th century Greek philosopher Aristippus who considered that the goal of life is to experience as much pleasure as possible and the avoidance of pain. The eudaimonic view is connected to Aristotle and relates to the realisation of human potential focusing on psychological well-being connected to meaningful and valuable actions or activities. 
One of the most neglected emotions and the most underestimated of the virtues in positive psychology is gratitude (Emmons \& Crumpler, 2000). This review found that only three studies examined gratitude in a tourism context. Gratitude and kindness are two important emotions that are missing from tourism studies (Filep et al., 2017; Glover \& Filep, 2015). This review also indicated a lack of studies on eudaimonic well-being. Studies that have examined eudaimonic well-being include $\mathrm{Li}$ and Chan (2017) on diaspora and eudaimonic well-being and Rahmani, Gnoth \& Mather (2018) on a psycholinguistic view of hedonic and eudaimonic well-being. Therefore, this review supports the proposal by Sirgy and Uysal (2016) for tourism scholars to develop a eudaimonia research agenda in travel and tourism as the focus on the quest for self-development and transformation has become a central concern of the western tourist society.

Although the 82 peer-reviewed articles applied 28 theories and models, not all theories were drawn from the positive psychology discipline. This paper therefore supports the observation by Ryff (2003) that there is a general tendency for behavioural scientists not to read and cite the broader literature. For example, Nusair and Parsa (2011) and Cheng and Lu (2015) used the Flow Theory but did not refer to positive psychology. Voigt, Howat and Brown, (2010) employed Stebbin's framework of casual versus serious leisure to explore whether tourism experience could be classified into hedonic or eudaimonic experiences. Likewise, Pyke, Hartwell, Blake \& Hemingway (2016) employed a systems theory approach to understand how tourism investors viewed the concept of well-being in relation to tourism and the potential to use it as a tourism product resource.

Although there has been a rapid growth of studies which have applied positive psychology concepts and principles (Filep \& Laing, 2018), this review has also shown that the application of positive psychology theoretical frameworks in tourism research appears to be limited to the broaden and build theory of positive emotions, flow theory, self-determination 
theory (SDT) and the PERMA model. Flow theory and SDT theory are established psychological theories, which highlight factors that contribute to optimal learning, engagement and motivation. It is argued that although positive and humanistic psychology overlap in thematic and theoretical content, positive psychology explicitly distances itself as a new movement. Therefore, some theories may overlap between the two disciplines. The difference between humanistic psychology and positive psychology is that positive psychology emphasizes heavily on traditional scientific empirical research. Gable and Haidt (2005) argue that before the launch of positive psychology as an established research field at the start of the millennium, less was known in psychology about conditions for human flourishing and wellbeing, character strengths and virtues and civic engagement as opposed to other aspects of the human condition such as alleviation of depression. Positive psychologists also focus more on the benefits of happiness and satisfaction with life than do humanistic psychologists (Compton,

2005). Positive psychology has been viewed as the "fourth wave" in the evolution of psychology. The first three waves being, respectively, the disease model, behaviourism and humanistic psychology (Becker \& Marecek, 2008). The central theme in positive psychology revolves around well-being and the enhancement of quality of life. There are also existing studies which relate the flow theory and SDT theory to the positive psychology discipline (Mackenzie, Son \& Eitel, 2018).

\subsection{Methodological frameworks}

The findings of this review showed that there was a balance in the use of both quantitative and qualitative approaches in existing research. This finding is aligned to Filep and Laing (2018) who suggest that as the tourism literature welcomes both quantitative and qualitative contributions, it therefore has a less positivist flavour than that which characterizes mainstream positive psychology. Whilst there have been critiques of the absence of the use of positive 
psychology interventions (PPIs) in tourism such as lab experiments (Nawijn, 2015), it has been argued that the support of positive psychology topics in tourism research is for critical evaluation and not necessarily the adoption of all its techniques and practices (Filep \& Pearce, 2013).

\subsection{Research Focus}

There was minimal focus on host residents or host communities and tourism workers. Therefore, the application of positive psychology in tourism research examines subjective level positive emotions, happiness and satisfaction in life, and individual courage, honesty or wisdom (Seligman \& Csikszentmihalyi, 2000). There is evidence in this review of a need for future studies to be applied at the group or societal level where the focus is on the development, creation and maintenance of positive institutions such as the host communities and tourism workers.

\subsection{Geographical setting and research samples}

Based on the first author affiliation, most articles were published in developed countries such as Australia, USA, Netherlands, New Zealand and United Kingdom. This finding is significant because it supports the claim by Henrich, Heine, and Norenzayan (2010) that behavioural scientists routinely publish broad claims about human psychology and behaviour based on samples drawn entirely from western, educated, industrialized, rich and democratic societies. Western cultures are generally characterized as valuing individual achievement, self-worth, and personal freedoms (Kim, Choi, Knutson \& Borchgrevink, 2017) whilst Eastern countries differ significantly in cultural characteristics from their counterparts in Western countries (Hofstede, 2003). As culture can significantly influence travellers' expectations and 
perceptions (Zhang, Li, \& Law, 2015), this review therefore highlights a need for tourism scholars, specifically in Eastern countries or within Less Developed Countries

Based on the foregoing discussion, Figure 7 presents an overall representation of the findings of this review, which maps existing literature and future research on positive psychology and tourist well-being studies in tourism research.

--- About insert Figure 7 here please---

\section{Theoretical contributions}

The main aim of this review was to present a conceptual framework on the implications of tourist well-being on tourism marketing and management. The findings from this review have indicated that tourist well-being has predominantly been examined as an outcome variable, and there is an evident need to link tourist well-being to practical outcomes that would be beneficial to tourism operators. Specifically, this review has shown that existing studies on positive psychology and tourist well-being in tourism research are focused on three main areas: 1) antecedents or triggers of tourist well-being; 2) episodes or consumption contexts of tourist well-being; and 3) consequences or the benefits of tourist well-being. This review indicates that the benefits of tourist well-being have implications for tourism marketing and management, specifically in the areas of behavioural intentions and destination attachment.

\subsection{Antecedents}

The findings from this review have shown that there are specific triggers, which contribute to or influence tourist well-being. Some of these triggers include the variables of happiness, positive emotions, savouring, character strengths, gratitude, humour, mindfulness, engagement, relationships, meaning and accomplishment. This review also reveals the use of 
few positive psychological theories to explain how these variables influence tourist well-being. The broaden and build theory of positive emotions (Fredrickson, 2004a) was the most commonly applied positive psychological theory. The flow theory (Csikszentmihalyi, 1975) was also applied within the context of white-water rafting (Wu \& Liang, 2011), online shopping in travel (Nusair \& Parsa, 2011), adventure tourism (Mackenzie et al., 2018), surfing activities (Cheng \& Lu, 2015) and mountain holidays (Frochot et al., 2017). In addition, the PERMA model of well-being comprising of five building blocks of well-being and happiness: positive emotions, engagement, relationships, meaning and achievement (Seligman, 2004). These positive psychological theories have been applied in existing conceptual and empirical papers to explain tourist well-being from the lens of positive psychology.

\subsection{Episodes}

The findings from the existing literature have also shown that tourist well-being are influenced by interaction with the natural and social environment which are present in certain tourism experiences such as wellness tourism, yoga tourism or volunteer tourism. Direct experiences in nature can promote emotional affinity towards nature (Ballantyne \& Packer, 2013) and acts of kindness can enhance emotional connection to host communities (Filep, Macnaughton \& Glover, 2017). In the tourism context, experiences in rural tourism (Sharpley \& Jepson, 2011) and wildlife tourism (Curtin, 2009) have also been linked to well-being. Museums (Packer, 2013), urban parks (Chiesura, 2004), zoos and aquariums (Falk et al., 2007) have also been found to be restorative environments. A study by Wolf, Stricker, and Hagenloh (2015) also found that participants at thematically connected guided walking, biking and 4WD tours in Australian national parks developed strong ties with community members and experienced significant improvements in health, well-being and competence. However, this review also 
identified that the tourism consumption contexts in existing research were mostly confined to western countries such as Australia, New Zealand, Netherlands and the USA.

\subsection{Consequences}

The benefits of experiencing tourist well-being promotes tourist health by enhancing one's inner self, belongingness to a social world and reinforces the ability to cope with the stresses of everyday life. The findings of this review has shown that the benefits of experiencing constructs of well-being within tourism, such as the presence of silence (Dillette, Douglas, \& Andrzejewski, 2018), acts of kindness (Filep et al., 2017), and meaning from vacation experiences such as wellness tourism and yoga tourism (Voigt et al., 2011) has also resulted in behavioural consequences. These behavioural consequences have significant implications for tourism marketing and management as it relates to revisit intentions, positive word of mouth (WOM) and destination attachment.

Existing studies from this review suggest that there is a relationship between tourist well-being and behavioural intentions. For example, Lin (2012) found that cuisine experience influenced psychological well-being, which consequently affected tourists revisit intentions. The motivation and subjective well-being of hiking tourists also affected the intention to revisit (Kim, Lee, Uysal, Kim \& Ahn, 2015). Furthermore, Reitsamer \& Brunner-Sperdin (2015) found that tourists' well-being had a positive impact on their intention to return and the desire to engage in positive WOM.

The findings from this review also indicate a relationship between tourist well-being and destination attachment. For example, participants' levels of self-esteem and belonging increased when visualizing a place of attachment, compared to visualizing a non-attached familiar place (Scannell \& Gifford, 2017). In addition, individuals feel a sense of belonging and purpose when they establish a harmonious attachment and identity to a specific place 
(Aitken \& Campelo, 2011). An attachment to favourite places also influences revisitation for rest and relaxation (Korpela \& Ylén, 2007; Korpela, Ylén, Tyrväinen, \& Silvennoinen, 2010). Furthermore, Moss (2009) found that a better understanding of individual well-being and quality of life can be understood by the relationship that people have with their own living environment.

Furthermore, this review has found that the significant contribution of tourist wellbeing also extends beyond the individual and towards the society in terms of positive attitudes towards poverty alleviation and development issues (Pearce, 2012) and residents participation in value co-creation with tourists (Lin et al., 2017). Therefore, based on the foregoing discussion, this study presents a conceptual framework (see Figure 8) which contributes to existing literature by providing an overall understanding of the antecedents, episodes and consequences of tourist well-being. This framework is significant because it indicates the need for tourist well-being to be examined beyond the boundaries of an outcome variable by understanding the contribution of tourist well-being to tourism marketing and management.

--- About insert Figure 8 here please---

\section{Practical implications}

This study also recommends practical strategies for tourism marketers and managers. Firstly, this review has found that tourist well-being is influenced by positive psychological variables such as happiness, character strengths, gratitude and humour. Therefore, tourism marketers should enhance these variables through visuals (images and texts) in destination marketing and promotional collaterals as these may influence tourists' choice of a destination and, subsequently, revisit intentions and positive WOM which would enhance the economic benefits for tourism destinations. 
Secondly, tourism marketers should expand general tourist or customer satisfaction questionnaires beyond satisfaction ratings. Other measures such as positive emotions, achievement and personal growth shoud be considered as these variables are found to influence well-being (Vada, Prentice \& Hsiao, 2019). This information would be significant as it can assist in the development of tourism products and services, which would maximize tourist satisfaction in ways that contribute to life satisfaction and tourists' quality of life. In addition, tourism marketers should promote staycations (during weekends) as a healthy and affordable option which captures well-being during a shorter period of time. Staycations refers to vacations at a person's usual domicile (de Bloom, Nawijn, Geurts, Kinnunen \& Korpela, (2017). Such tourism products and services may influence behavioural intentions and destination attachment.

Finally, this review has found that tourist well-being is more than just a physical activity and is also influenced by activities or experiences which enhance social relationships, learning a new culture or developing a new skill. Wellness products and services are generally perceived as luxurious and expensive, therefore, by offering reasonable and cost-effective activities such as volunteering activities or home-stay options in host communities would allow tourists to learn about a new culture and connect with the local people. Therefore, these initiatives would not only support well-being amongst tourists and residents in host communities, but would also enhance the sustainability of tourist destinations.

\section{Conclusion}

This study mapped the current state of knowledge from academic papers on the intersection between positive psychology and tourist well-being studies in tourism research. Through a systematic quantitative review, this study synthesized 82 peer-reviewed articles to examine the theoretical and methodological frameworks applied from positive psychology to the study of 
tourist well-being, the geographical settings and research samples, and the opportunities for future research in this growing area of interest. This study has shown that despite an increasing number of studies which have applied positive psychology concepts to the study of tourist wellbeing, the platform of tourism scholarship that directly explores tourist well-being is not well established (Filep \& Laing, 2018). Pearce (2009) argued that positive psychology has the power to change the way that tourist behaviour is studied. This study has laid the groundwork by mapping what is known and yet to be known in the relationship between positive psychology and tourist well-being studies. By providing future directions for research, tourism scholars will be able to contribute further to this growing area and the emerging field of 'positive tourism' (Filep, Laing \& Csikszentmihalyi, 2016). Through a conceptual framework, this paper has also contributed to a better understanding of the antecedents, episodes and consequences of tourist well-being from the lens of positive psychology in tourism research. More significantly, this study has provided practical strategies whereby tourist well-being can be utilised to generate optimal outcomes for tourism marketers and managers.

\section{Limitations and future research}

A limitation of a systematic quantitative literature review method is the selection of the research terms and the scope of research. The search terms employed in this review were limited to positive psychology, happiness and well-being as informed by previous literature. This systematic quantitative literature review was also limited to peer-reviewed articles in English-language academic journals. This may have restricted relevant articles published in different languages or in other sources such as books. Based on the limitations and findings from this review, this study proposes the following areas for future research.

- Future reviews should include other concepts linked to positive psychology such as positive emotions, character strengths, gratitude and humour. Negative emotions may also be 
applied as a search term as eudaimonic well-being can result from activities that are not particularly pleasant at the time but may have delayed positive effects that occur when results are achieved such as increased skill level or reaching a goal (Huta, 2013). The inclusion criteria may also include non-English language academic journals and a wider source of materials

- Future research could use other theories from positive psychology such as the top-down, bottom-up theories of well-being

- Future studies to be applied at the group or societal level where the focus is on the development, creation and maintenance of positive institutions such as the host communities and tourism workers

- Future research could also apply recent methodologies, such as text topic modelling. This technique was used in a recent study by Rahmani, Gnoth and Mather (2018) which used text topic modelling to analyse big Web 2.0 datasets to measure how tourists' experiencing holiday destinations affect their well-being states. Text topic modelling allows researchers to categorise large datasets according to associations between terms and documents, thus bridging the gap between phenomenological and positivist research. These authors suggest that further development of this methodology could lead to deeper analysis of the semantics of experiencing, as and when concordances can be coded into algorithms that are more complex

- There is a need for studies with a wider geographical spread of research and the inclusion of non-Western research samples. Research is also needed on mature-aged travellers. Elderly and mature-aged travellers represent a third of all travellers and therefore deserves specific attention. Quality-of-life research may help to better understand the benefits derived by this group from travelling (Moal-Ulvoas, 2017).

\section{References}

Aitken, R., \& Campelo, A. (2011). The four Rs of place branding. Journal of Marketing Management, 27(9-10), 913-933. doi: 10.1080/0267257X.2011.560718

Bandara, W., Furtmueller, E., Gorbacheva, E., Miskon, S., \& Beekhuyzen, J.P. (2015). Achieving Rigor in Literature Reviews: Insights from Qualitative Data Analysis and 
Tool-Support. Communication of the Association for Information Systems, 34(8), 154204.

Becker, D., \& Marecek, J. (2008). Positive Psychology: History in the Remaking? Theory \& Psychology, 18(5), 591-604. doi:10.1177/0959354308093397

Breiby, M. A., \& Slåtten, T. (2015). The Effects of Aesthetic Experiential Qualities on Tourists Positive Emotions and Loyalty: A Case of a Nature-Based Context in Norway. Journal of Quality Assurance in Hospitality \& Tourism, 16(4), 323-346.

doi: 10.1080/1528008X.2015.1016591

Chen, Y., Lehto, X. Y., \& Cai, L. (2013). Vacation and well-being: A study of Chinese tourists. Annals of Tourism Research, 42, 284. doi:10.1016/j.annals.2013.02.003

Cheng, T.-M., \& Lu, C.-C. (2015). The Causal Relationships among Recreational Involvement, Flow Experience, and Well-being for Surfing Activities. Asia Pacific Journal of Tourism Research, 20(1), 1486-1504. doi:10.1080/10941665.2014.999099

Coghlan, A. (2015). Tourism and health: using positive psychology principles to maximise participants' wellbeing outcomes-A design concept for charity challenge tourism. Journal of Sustainable Tourism, 23(3), 382-400. doi: 10.1080/09669582.2014.986489

Compton, W. C. (2005). Introduction to Positive Psychology. Virginia: Thomson Wadsworth. Csikszentmihalyi, M. (1975). Play and Intrinsic Rewards. Journal of Humanistic Psychology, 15(3), 41-63. doi:10.1177/002216787501500306

de Bloom, J., Geurts, S. A., \& Kompier, M. A. (2013). Vacation (after-) effects on employee health and well-being, and the role of vacation activities, experiences and sleep. Journal of Happiness Studies, 14(2), 613-633. doi: 10.1007/s10902-012-9345-3

de Bloom, J., Nawijn, J., Geurts, S., Kinnunen, U., \& Korpela, K. (2017). Holiday travel, staycations, and subjective well-being. Journal of Sustainable Tourism, 25(4), 573-588. doi: $10.1080 / 09669582.2016 .1229323$ 
de Menezes, L.M., \& Helliher, C. (2011). Flexible working and performance: A systeamtic review of the evidence for a business case. International Journal of Management Reviews, 13(4), 452-474. doi: 10.1111/j.1468-2370.2011.00301

Diener. (1984). Subjective well-being. Psychological Bulletin, 95(3), 542-575.

doi: $10.1037 / / 0033-2909.95 .3 .542$

Dillette, A. K., Douglas, A. C., \& Andrzejewski, C. (2018). Yoga tourism-a catalyst for transformation? Annals of Leisure Research, 1-20. doi:10.1080/11745398.2018.1459195

Elos, S., \& Kungas, H. (2008). The qualitative content analysis process. Journal of Advanced Nursing, 62(1), 107-115. doi: 10.1111/j.1365-2648.2007.04569.x

Emmons, R. A., \& Crumpler, C. A. (2000). Gratitude as a human strength: Appraising the evidence. Journal of Social and Clinical Psychology, 19(1), 56-69. doi: $10.1521 /$ jscp.2000.19.1.56

Filep, S. (2008). Applying the dimensions of flow to explore visitor engagement and satisfaction. Visitor Studies, 11, 90-108. doi: 10.1080/10645570801938491

Filep, S. (2009). Tourists' happiness through the lens of positive psychology (Unpublished doctoral dissertation). James Cook University, Australia.

Filep, S. (2016). Tourism and positive psychology critique: Too emotional? Annals of Tourism Research, 59, 113-115. doi:10.1016/j.annals.2016.04.004

Filep, S., Cao, D., Jiang, M., \& DeLacy, T. (2013). Savouring tourist experiences after a holiday. Leisure/Loisir, 37(3), 191-203. doi: 10.1080/14927713.2013.842731

Filep, S., \& Deery, M. (2010). Towards a picture of tourists' happiness. Tourism Analysis, 15(4), 399-410. doi:10.3727/108354210X12864727453061

Filep, S., \& Laing, J. Trends and directions in tourism and positive psychology. Journal of Travel Research, 1-12. doi:10.1177/0047287518759227 
Filep, S., Laing, J., \& Csikszentmihalyi, M. (2016). Positive tourism. Taylor \& Francis. New York.

Filep, S., Macnaughton, J., \& Glover, T. (2017). Tourism and gratitude: Valuing acts of kindness. Annals of Tourism Research, 66, 26-36. doi: 10.1016/j.annals.2017.05.015

Filep, S., \& Pearce, P. (2013). Tourist experience and fulfilment: Insights from Positive Psychology (Vol. 31). Routledge. New York.

Filo, K., \& Coghlan, A. (2016). Exploring the positive psychology domains of well-being activated through charity sport event experiences. Event Management, 20(2), 181-199. doi: $10.3727 / 152599516 X 14610017108701$

Fredrickson, B. L. (2004a). The broaden-and-build theory of positive emotions. Philosophical Transactions of the Royal Society B: Biological Sciences, 359(1449), 1367. doi: $10.1098 /$ rstb.2004.1512

Fredrickson, B. L. (2004b). Gratitude, like other positive emotions, broadens and builds. In R.A. Emmons \& M.E. McCullough (Eds.), Series in affective science. The psychology of gratitude (145-166), Oxord University Press. New York.

Fredrickson, B. L., \& Branigan, C. (2005). Positive emotions broaden the scope of attention and thought-action repertoires. Cognition \& Emotion, 19(3), 313-332. doi: $10.1080 / 02699930441000238$

Fredrickson, B. L., Tugade, M. M., Waugh, C. E., \& Larkin, G. R. (2003). What good are positive emotions in crisis? A prospective study of resilience and emotions following the terrorist attacks on the United States on September 11th, 2001. Journal of Personality and Social psychology, 84(2), 365 - 376. doi: 10.1037/0022-3514.84.2.365

Frochot, I., Elliot, S., \& Kreziak, D. (2017). Digging deep into the experience-flow and immersion patterns in a mountain holiday. International Journal of Culture, Tourism and Hospitality Research, 11(1), 81-91. doi: 10.1108/IJCTHR-09-2015-0115 
Gable, S., \& Haidt, J. (2005). What (and why) is positive psychology? Review of General Psychology, 9(2), 103-110. doi: 10.1037/1089-2680.9.2.103

Gilbert, D., \& Abdullah, J. (2004). Holidaytaking and the sense of well-being. Annals of Tourism Research, 31(1), 103-121. doi: 10.1016/j.annals.2003.06.001

Glover, T. D., \& Filep, S. (2015). On kindness of strangers in tourism. Annals of Tourism Research, 50 (1), 159-162. doi: 10.1016/j.annals.2014.11.010

Green, B. N., Johnson, C. D., \& Adams, A. (2006). Writing narrative literature reviews for peer-reviewed journals: Secrets of the trade. Journal of Chiropractic Medicine, 5(3), 101-117. doi: 10.1016/S0899-3467(07)60142-6

Henrich, J., Heine, S. J., \& Norenzayan, A. (2010). The weirdest people in the world? Behavioral and Brain Sciences, 33(2-3), 61-83. doi: 10.1017/S0140525X0999152X

Houge, S.M., Hodge, K., \& Boyes, M. (2013). The multiphasic and dynamic nature of flow in adventure experiences. Journal of Leisure Research, 45(2), 214-232. doi: 10.18666/j1r2013-v45-i2-3012

Lee, H.S., \& Bai, B. (2014). Hotel discount strategies on consumer responses: the role of involvement. Tourism Review, 69(4), 284-296. doi: 10.1108/TR-04-2014-0014

Io, M-U. (2017). Understanding the effects of multi-dimensional tourism experiences on tourists' positive emotions and satisfaction in the context of casino hotels. International Journal of Culture, Tourism and Hospitality Services, 11(2), 142-156. doi: 10.1108/IJCTHR-05-2016-0050

Kalaiya, A. B., \& Kumar, A. (2018). The role of psychology and its impact on tourist vacation satisfaction-An analysis of PERMA Model. International Journal of Advanced Research in Computer Science and Management Studies, 6(3), 57-63. 
Kim, H., Lee, S., Uysal, M., Kim, J. \& Ahn, K. (2015). Nature-based tourism: motivation and subjective well-being. Journal of Travel and Tourism Marketing, 32(1), 76-96. doi: $10.1080 / 10548408.2014 .997958$

Korpela, K. M., \& Ylén, M. (2007). Perceived health is associated with visiting natural favourite places in the vicinity. Health \& Place, 13(1), 138-151.

Korpela, K. M., Ylén, M., Tyrväinen, L., \& Silvennoinen, H. (2010). Favorite green, waterside and urban environments, restorative experiences and perceived health in Finland. Health Promotion International, 25(2), 200-209. doi:10.1093/heapro/daq007

Laing, J. H., \& Frost, W. (2017). Journeys of well-being: Women's travel narratives of transformation and self-discovery in Italy. Tourism Management, 62, 110-119. doi: 10.1016/j.tourman.2017.04.004

Lee, J. J., \& Kyle, G. T. (2013). The measurement of emotions elicited within festival contexts: A psychometric test of a Festival Consumption Emotions (FCE) Scale. Tourism Analysis, 18(6), 635-649. doi: 10.3727/108354213X13824558188541

Li, T. E., \& Chan, E. T. H. (2017). Diaspora tourism and well-being: A eudaimonic view. Annals of Tourism Research, 63(12), 205-206. doi:10.1016/j.annals.2017.01.005

Lin, C-H. (2012). Effects of cuisine experience, psychological well-being and self health perception on the revisit intentions of hot springs tourists. Journal of Travel Research, $38(2), 243-265$.

Lin, Z., Chen, Y., \& Filieri, R. (2017). Resident-tourist value co-creation: The role of residents' perceived tourism impacts and life satisfaction. Tourism Management, 61, 436-442. doi: 10.1016/j.tourman.2017.02.013

Lin, C-H., \& Kuo, B. Z.-L. (2016). The behavioral consequences of tourist experience. Tourism Management Perspectives, 18, 84-91. doi: 10.1016/j.tmp.2015.12.017 
Lyubomirsky, S., King, L., \& Diener, E. (2005). The benefits of frequent positive affect: Does happiness lead to success? Psychological Bulletin, 131(6), 803-823. doi: 10.1037/0033-2909.131.6.803

Mackenzie, S. H., Son, J. S., \& Eitel, K. (2018). Using outdoor adventure to enhance intrinsic motivation and engagement in science and physical activity: An exploratory study. Journal of Outdoor Recreation and Tourism, 21, 76-86. doi: 0.1016/j.jort.2018.01.008

Matteucci, X., \& Filep, S. (2017). Eudaimonic tourist experiences: The case of flamenco. Leisure Studies, 36(1), 39-52. doi: 10.1080/02614367.2015.1085590

Mays, N., Pope, C., \& Popay, J. (2005). Systematically reviewing qualitative and quantitative evidence to inform management and policy-making in the health field. Journal of Health Services Research \& Policy, 10(1_suppl), 6-20. doi: $10.1258 / 1355819054308576$

McCabe, S., \& Johnson, S. (2013). The happiness factor in tourism: Subjective well-being and social tourism. Annals of Tourism Research, 41, 42-65. doi: 10.1016/j.annals.2012.12.001

Miao, F. F., Vittersø, J., Ferssizidis, P., Fredrickson, B. L., Steger, M. F., Catalino, L. I., Ryan, R. M. (2013). Functional well-being: Happiness as feelings, evaluations, and functioning (Vol. 1). Oxford University Press. UK.

Mitas, O., Qian, X. L., Yarnal, C., \& Kerstetter, D. (2011). “The fun begins now!”: Broadening and building processes in Red Hat Society ${ }^{\circledR}$ participation. Journal of Leisure Research, 43(1), 30-55.

Mitas, O., Yarnal, C., \& Chick, G. (2012). Jokes build community: Mature tourists' positive emotions. Annals of Tourism Research, 39(4), 1884-1905. doi: 10.1016/j.annals.2012.05.003 
Moal-Ulvoas, G. (2017). Positive emotions and spirituality in older travelers. Annals of Tourism Research, 66, 151-158. doi:10.1016/j.annals.2017.07.020

Morgan, N., Pritchard, A., \& Sedgley, D. (2015). Social tourism and well-being in later life. Annals of Tourism Research, 52, 1-15. doi:10.1016/j.annals.2015.02.015

Moscardo, G. (2009). Tourism and quality of life: towards a more critical approach. Tourism and Hospitality Research. 9(2), 159-170. doi: 10.1057/thr.2009.6

Moser, G. (2009). Quality of life and sustainability: Toward person-environment congruity. Journal of Environmental Psychology, 29(3), 351-357.

Nawijn, J. (2011). Happiness through vacationing: Just a temporary boost or long-term benefits? Journal of Happiness Studies, 12(4), 651-665. doi: 10.1007/s10902-010-9221-y

Nawijn, J. (2011). Determinants of daily happiness on vacation. Journal of Travel Research, 50(5), 559-566. doi: 10.1177/0047287510379164

Nawijn, J. (2015). Positive psychology in tourism: A critique. Annals of Tourism Research, 56(14), 151-153. doi:10.1016/j.annals.2015.11.004

Nawijn, J., \& Filep, S. (2016). Two directions for future tourist well-being research. Annals of Tourism Research, 61(C), 221-223. doi: 10.1016/j.annals.2016.07.007

Nawijn, J., Marchand, M. A., Veenhoven, R., \& Vingerhoets, A. J. (2010). Vacationers happier, but most not happier after a holiday. Applied Research in Quality of Life, 5(1), 35-47. doi: 10.1007/s11482-009-9091-9

Nawijn, J., Mitas, O., Lin, Y., \& Kerstetter, D. (2013). How do we feel on vacation? A closer look at how emotions change over the course of a trip. Journal of Travel Research, 52(2), 265-274. doi: 10.1177/0047287512465961

Nawijn, J., \& Peeters, P. M. (2010). Travelling 'green': is tourists' happiness at stake? Current Issues in Tourism, 13(4), 381-392. doi:10.1080/13683500903215016 
Nusair, K., \& Parsa, H. (2011). Introducing flow theory to explain the interactive online shopping experience in a travel context. International Journal of Hospitality \& Tourism Administration, 12(1), 1-20. doi: 10.1080/15256480.2011.540974

Organ, K., Koenig-Lewis, N., Palmer, A., \& Probert, J. (2015). Festivals as agents for behaviour change: A study of food festival engagement and subsequent food choices. Tourism Management, 48, 84-99. doi: 10.1016/j.tourman.2014.10.021

Pearce, P. L. (2009). The relationship between positive psychology and tourist behavior studies. Tourism Analysis, 14(1), 37-48. doi: 10.3727/108354209788970153

Pearce, P. L. (2012). Tourists' written reactions to poverty in Southern Africa. Journal of Travel Research, 51(2), 154-165. doi: 10.1177/0047287510396098

Pearce, P. L., \& Pabel, A. (2013). Humour, tourism and positive psychology in Tourist Experience and fulfilment: Insights from Positive Psychology, Routledge, New York. $17-36$.

Petticrew, M. (2001). Systematic reviews from astronomy to zoology: myths and misconceptions. British Medical Journal, 322(7278), 98-101. doi: $10.1136 / \mathrm{bmj} .322 .7278 .98$

Pickering, C., \& Byrne, J. (2014). The benefits of publishing systematic quantitative literature reviews for $\mathrm{PhD}$ candidates and other early-career researchers. Higher Education Research \& Development, 33(3), 534-548. doi: 10.1080/07294360.2013.841651

Pickering, C., Grignon. J., Steven, R., \& McLennan, C.I.J. (2015). Publishing not perishing. How research students transition from notice to knowledgeable using systematic quantiative literature reviews. Studies in Higher Education, 40(10), 1756-1769. doi: $10.1080 / 03075079.2014 .914907$ 
Pyke, S., Hartwell, H., Blake, A., \& Hemingway, A. (2016). Exploring well-being as a tourism product resource. Tourism Management, 55, 94-105. doi: 10.1016/j.tourman.2016.02.004

Rahmani, K., Gnoth, J., \& Mather, D. (2018). Hedonic and eudaimonic well-being: A psycholinguistic view. Tourism Management, 69(12), 155-166. doi: 10.1016/j.tourman.2018.06.008

Reitsamer, B., \& Brunner-Sperdin. (2015). Tourist destination perception and well-being: What makes a destination attractive? Journal of Vacation Marketing, 23(1), 55-72.

Saunders, R., Laing, J., \& Weiler, B. (2013). Personal transformation through long-distance walking in Tourist Experience and fulfilment: Insights from Positive Psychology, Routledge, New York.

Scannell, L., \& Gifford, R. (2017). Place Attachment Enhances Psychological Need Satisfaction. Environment and behavior, 49(4), 359-389. doi:10.1177/0013916516637648

Seligman, M. E. (2004). Authentic happiness: Using the new positive psychology to realize your potential for lasting fulfillment. Simon and Schuster. New York.

Seligman, M. E., \& Csikszentmihalyi, M. (2000). Positive psychology: An introduction. American Psychological Association, 55(1), 5-14.

Sirgy, M. J., \& Uysal, M. (2016). Developing a eudaimonia research agenda in travel and tourism. Handbook of Eudaimonic Well-Being (pp. 485-495): Springer. Switzerland.

Smith, M. K., \& Diekmann, A. (2017). Tourism and wellbeing. Annals of Tourism Research, 66, 1-13. doi: 10.1016/j.annals.2017.05.006

Spasojevic, B., Lohmann, G., \& Scott, N. (2018). Air transport and tourism - a systematic literature review (2000-2014). Current Issues in Tourism, 21(9), 975-997. doi: 10.1080/13683500.2017.1334762 
Taylor, E. (2001). Positive psychology and humanistic psychology: A reply to Seligman. Journal of Humanistic Psychology, 41(1), 13-29. doi: 10.1177/0022167801411003

Torres, E., Wei, W., \& Hua, N. (2017). Towards understanding the effects of time and emotions on the vacation experience. Tourism Review, 72(4), 357-374.

doi: 10.1108/TR-05-2017-0088

Tranfield, D., Denyer, D., \& Smart, P. (2003). Towards a methodoogy for developing evidence: Informed Management Knowledge by Means of Systematic Review. British Journal of Management, 14, 207-222. doi: 10.1111/1467-8551.00375

Tugade, M. M., \& Fredrickson, B. L. (2004). Resilient individuals use positive emotions to bounce back from negative emotional experiences. Journal of Personality and Social Psychology, 86(2), 320-333. doi: 10.1037/0022-3514.86.2.320

Vada, S., Prentice, C. \& Hsiao, A. (2019). The role of positive psychology in behavioural intentions. Journal of Retailing and Consumer Services, 51, 293-303. doi.org/10.1016/j.jretconser.2019.06.015

Voigt, C., Howat, G., \& Brown, G. (2010). Hedonic and eudaimonic experiences among wellness tourists: An exploratory study. Annals of Leisure Research, 1(13), 541-562. doi: $10.1080 / 11745398.2010 .9686862$

Waterman, A. S., Schwartz, S. J., Zamboanga, B. L., Ravert, R. D., Williams, M. K., Bede Agocha, V., Brent Donnellan, M. (2010). The questionnaire for eudaimonic well-being: Psychometric properties, demographic comparisons, and evidence of validity. The Journal of Positive Psychology, 5(1), 41-61. doi: 10.1080/17439760903435208

Watson, D., Clark, L. A., \& Tellegen, A. (1988). Development and validation of brief measures of positive and negative affect: The PANAS scales. Journal of Personality and Social Psychology, 54(6), 1063-1070. doi: 10.1037/0022-3514.54.6.1063 
Watson, R., Wilson, H.N., \& Macdonald, E.K. (2018). Harnessing Difference: A CapabilityBased Framework for Stakeholder Engagement in Environmental Innovation. Journal of Product Innovation Management, 35(2), 254-79. doi: 10.1111/jpim.12394

Williams, K. H., Childers, C., \& Kemp, E. (2013). Stimulating and enhancing student learning through positive emotions. Journal of Teaching in Travel \& Tourism, 13(3), 209-227. doi: $10.1080 / 15313220.2013 .813320$

Wu, C. H.-J., \& Liang, R.-D. (2011). The relationship between white-water rafting experience formation and customer reaction: A flow theory perspective. Tourism Management, 32(2), 317-325. doi: 10.1016/j.tourman.2010.03.001

Wu, M., \& Pearce, P.L. (2014). Positive psychology and its application in tourism studies. Tourism Tribune, 29(1), 39-46.

Yang, E. C. L., Khoo-Lattimore, C., \& Arcodia, C. (2017). A systematic literature review of risk and gender research in tourism. Tourism Management, 58, 89-100. doi: 10.1016/j.tourman.2016.10.011

Yung, R., \& Khoo-Lattimore, C. (2017). New realities: a systematic literature review on virtual reality and augmented reality in tourism research. Current Issues in Tourism, 1-26. doi: $10.1080 / 13683500.2017 .1417359$

Yau, M. K.-S., \& Packer, T. L. (2002). Health and well-being through T 'ai Chi: Perceptions of older adults in Hong Kong. Leisure Studies, 21(2), 163-178. doi: $10.1080 / 026143602110138850$

Zhang, Z., Li, H., \& Law, R. (2015). Differences and similarities in perceptions of hotel experience: The role of national cultures. Journal of Travel \& Tourism Marketing, 32(1), 2-14. doi:10.1080/10548408.2014.959153 


\section{APPENDICES}

Table 1: Seminal papers on positive psychology and tourism research

\begin{tabular}{|c|c|c|c|c|}
\hline Author & Date & Title & Journal and rank & Key words \\
\hline Filep, S. & 2008 & $\begin{array}{l}\text { Applying the dimensions of } \\
\text { flow to explore visitor } \\
\text { engagement and satisfaction }\end{array}$ & Visitor studies (A) & $\begin{array}{l}\text { Positive } \\
\text { psychology, } \\
\text { tourist } \\
\text { satisfaction }\end{array}$ \\
\hline Pearce, P.L. & 2009 & $\begin{array}{l}\text { The relationship between } \\
\text { positive psychology and } \\
\text { tourist behaviour studies }\end{array}$ & $\begin{array}{l}\text { Tourism Analysis } \\
\text { (A) }\end{array}$ & $\begin{array}{l}\text { Positive } \\
\text { psychology, } \\
\text { happiness, well- } \\
\text { being, positive } \\
\text { emotions, } \\
\text { optimism }\end{array}$ \\
\hline Moscardo, G. & 2009 & $\begin{array}{l}\text { Tourism and Quality of Life: } \\
\text { Towards a more critical } \\
\text { approach }\end{array}$ & $\begin{array}{l}\text { Tourism and } \\
\text { Hospitality } \\
\text { Research (A) }\end{array}$ & $\begin{array}{l}\text { Quality of life, } \\
\text { positive } \\
\text { psychology, } \\
\text { tourism impacts, } \\
\text { social } \\
\text { representations }\end{array}$ \\
\hline $\begin{array}{l}\text { Filep, S., \& } \\
\text { Deery, M }\end{array}$ & 2010 & $\begin{array}{l}\text { Towards a picture of tourists' } \\
\text { happiness }\end{array}$ & $\begin{array}{l}\text { Tourism Analysis } \\
\text { (A) }\end{array}$ & $\begin{array}{l}\text { Tourists, } \\
\text { happiness, } \\
\text { picture, positive } \\
\text { psychology }\end{array}$ \\
\hline $\begin{array}{l}\text { Nawijn, J. \& } \\
\text { Peeters, P. }\end{array}$ & 2010 & $\begin{array}{l}\text { Travelling 'green': is } \\
\text { tourists' happiness at stake? }\end{array}$ & $\begin{array}{l}\text { Current Issues in } \\
\text { Tourism (A) }\end{array}$ & $\begin{array}{l}\text { Air travel, climate } \\
\text { change, } \\
\text { sustainability, } \\
\text { happiness, } \\
\text { subjective well- } \\
\text { being }\end{array}$ \\
\hline $\begin{array}{l}\text { Voigt, C., } \\
\text { Howat, G., \& } \\
\text { Brown, G. }\end{array}$ & 2010 & $\begin{array}{l}\text { Hedonic and eudaimonic } \\
\text { experiences among wellness } \\
\text { tourists }\end{array}$ & $\begin{array}{l}\text { Annals of Leisure } \\
\text { Research (A) }\end{array}$ & $\begin{array}{l}\text { Positive } \\
\text { psychology, } \\
\text { psychological } \\
\text { well-being, } \\
\text { hedonic } \\
\text { wellbeing, } \\
\text { eudaimonic } \\
\text { wellbeing, } \\
\text { wellness tourism, } \\
\text { casual leisure, } \\
\text { serious leisure }\end{array}$ \\
\hline Nawijn, J. & 2011 & $\begin{array}{l}\text { Determinants of daily } \\
\text { happiness on vacation }\end{array}$ & $\begin{array}{l}\text { Journal of Travel } \\
\text { Research }\left(\mathrm{A}^{*}\right)\end{array}$ & $\begin{array}{l}\text { Affect, emotions, } \\
\text { happiness, } \\
\text { subjective well- } \\
\text { being, tourist } \\
\text { experience }\end{array}$ \\
\hline
\end{tabular}


Nawijn, J. 2015 Positive psychology in Annals of Tourism Positive tourism: a critique

Research $\left(\mathrm{A}^{*}\right) \quad$ psychology,

tourism, happiness, wellbeing

Filep, S. 2016 Tourism and positive Annals of Tourism Positive psychology critique: too Research $\left(\mathrm{A}^{*}\right)$ psychology, emotional? tourism, happiness, wellbeing, negative emotions

Nawijn, J., \& 2016 Two directions for future Annals of Tourism Positive Filep, $\mathrm{S}$ tourist well-being research Research $\left(\mathrm{A}^{*}\right)$ psychology, wellbeing 
Table 2. Search strings

Theme Search String

Positive psychology

Tourism

(positive psychology* OR happiness* OR well-being* OR tourism* OR tourist experience* OR travel*) 
Table 3: Inclusion and exclusion criteria

\begin{tabular}{|c|c|c|}
\hline Criterion & Inclusion & Exclusion \\
\hline Study & $\begin{array}{l}\text { Original empirical and theoretical/conceptual } \\
\text { studies }\end{array}$ & \\
\hline Type & Peer-reviewed journal articles & \\
\hline Language & English & Non-English language \\
\hline Sector & Tourism research & Non-tourism related focus \\
\hline Relevance & $\begin{array}{l}\text { Positive psychology concepts of happiness } \\
\text { and well-being }\end{array}$ & $\begin{array}{l}\text { Unrelated to positive } \\
\text { psychology concepts of } \\
\text { happiness and well-being }\end{array}$ \\
\hline
\end{tabular}


Table 4. Peer-reviewed articles by country

\begin{tabular}{|c|c|c|c|}
\hline No. & Country & No. of authors & $\%$ \\
\hline 1 & Australia & 17 & 9 \\
\hline 2 & U.S.A & 14 & 8 \\
\hline 3 & Netherlands & 12 & 7 \\
\hline 4 & New Zealand & 9 & 5 \\
\hline 5 & United Kingdom & 8 & 4 \\
\hline 6 & Taiwan & 3 & 2 \\
\hline 7 & Finland & 2 & 1 \\
\hline 8 & Norway & 2 & 1 \\
\hline 9 & South Africa & 2 & 1 \\
\hline 10 & France & 2 & 1 \\
\hline 11 & Hong Kong & 2 & 1 \\
\hline 12 & Italy & 2 & 1 \\
\hline 13 & Austria & 1 & 1 \\
\hline 14 & Canada & 1 & 1 \\
\hline 15 & Hungary & 1 & 1 \\
\hline 16 & India & 1 & 1 \\
\hline 17 & Switzerland & 1 & 1 \\
\hline 18 & China & 1 & 1 \\
\hline \multirow[t]{2}{*}{19} & Portugal & 1 & 1 \\
\hline & Total & 82 & 100 \\
\hline
\end{tabular}

(Based on first author affiliation) 
Table 5. Peer-reviewed articles by journal

\begin{tabular}{|c|c|c|c|}
\hline No. & Journal Name & No. of studies & $\%$ \\
\hline 1 & Annals of Tourism Research & 19 & 23 \\
\hline 2 & Tourism Management & 11 & 13 \\
\hline 3 & Journal of Hospitality and Tourism Research & 6 & 7 \\
\hline 4 & $\begin{array}{l}\text { Journal of Travel Research } \\
\text { International Journal of Culture, Tourism and }\end{array}$ & 5 & 6 \\
\hline 5 & Hospitality research & 4 & 5 \\
\hline 6 & Annals of Leisure Research & 3 & 4 \\
\hline 7 & Current Issues in Tourism & 3 & 4 \\
\hline 8 & Journal of Leisure Research & 3 & 4 \\
\hline 9 & Tourism Analysis & 2 & 2 \\
\hline 10 & Journal of Happiness Studies & 2 & 2 \\
\hline 11 & Leisure Sciences & 2 & 2 \\
\hline 12 & Journal of Travel and Tourism Marketing & 2 & 2 \\
\hline 13 & Journal of Sustainable Tourism & 2 & 2 \\
\hline 14 & Tourism Management Perspectives & 2 & 2 \\
\hline 15 & $\begin{array}{l}\text { Applied Research in Quality of Life } \\
\text { International Journal of Hospitality and Tourism }\end{array}$ & 1 & 1 \\
\hline 16 & Administration & 1 & 1 \\
\hline 17 & Leisure & 1 & 1 \\
\hline 18 & Tourism Review International & 1 & 1 \\
\hline 19 & International Journal of Tourism Research & 1 & 1 \\
\hline 20 & Event Management & 1 & 1 \\
\hline 21 & Asia Pacific Journal of Tourism Research & 1 & 1 \\
\hline 22 & Scandinavian Journal of Hospitality and Research & 1 & 1 \\
\hline 23 & $\begin{array}{l}\text { The Design Journal } \\
\text { Journal of Tourism, Culture and Territorial }\end{array}$ & 1 & 1 \\
\hline 24 & Development & 1 & 1 \\
\hline 25 & $\begin{array}{l}\text { International Journal of Advance Research in } \\
\text { Computer Science and Management Studies }\end{array}$ & 1 & 1 \\
\hline 26 & African Journal of Hospitality, Tourism and Leisure & 1 & 1 \\
\hline 27 & Advances in Hospitality and Leisure & 1 & 1 \\
\hline 28 & International Journal of Business and Social Science & 1 & 1 \\
\hline 29 & Leisure studies & 1 & 1 \\
\hline \multirow[t]{2}{*}{30} & Visitor Studies & 1 & 1 \\
\hline & Total & 82 & 100 \\
\hline
\end{tabular}


Table 6. Theoretical frameworks in peer-reviewed articles

\begin{tabular}{rlc}
\hline No. & Theoretical framework & No. of studies \\
\hline 1 & Broaden and build theory of positive emotions & 6 \\
2 & Flow theory & 5 \\
3 & PERMA model & 4 \\
4 & Mindfulness theory & 3 \\
5 & Set point theory & 2 \\
6 & Reversal theory & 2 \\
7 & Constructivist grounded theory & 2 \\
8 & Self-determination theory & 2 \\
9 & Effort recovery theory & 2 \\
10 & Savouring & 2 \\
11 & Subjective well-being model & 2 \\
12 & Quality of life framework & 1 \\
13 & Stebbin's theory of casual versus serious leisure & 1 \\
14 & Need theory & 1 \\
15 & Comparison theory & 1 \\
16 & Satisfaction hierarchy Model & 1 \\
17 & Appreciative inquiry & 1 \\
18 & Affective theory & 1 \\
19 & Cognitive theory of happiness & 1 \\
20 & Systems theory approach & 1 \\
21 & Conservations of resources theory & 1 \\
22 & DRAMMA model & 1 \\
23 & Social representation theory & 1 \\
24 & Construal level theory & 1 \\
25 & Limited resources Model & 1 \\
26 & Top-up and bottom-down theories of well-being & 1 \\
27 & Spillover theory of happiness & 1 \\
28 & Emotion regulation theory & 1 \\
& Total & 1 \\
\hline & & 1 \\
1 & \\
1
\end{tabular}


Table 7. Peer-reviewed articles by variables measured

\begin{tabular}{clc}
\hline No. & Concepts & No. of studies \\
\hline 1 & Happiness & 14 \\
2 & Well-being & 13 \\
3 & Emotions & 17 \\
4 & Life satisfaction & 8 \\
5 & Savouring & 5 \\
6 & Character strengths & 4 \\
7 & Quality of life & 4 \\
8 & Gratitude & 3 \\
9 & Humour & 2 \\
10 & Mindfulness & 2 \\
11 & Engagement & 2 \\
12 & Relationships & 2 \\
13 & Meaning & 2 \\
14 & Accomplishment & 2 \\
15 & Eudaimonia & 2 \\
& Total & 82 \\
\hline
\end{tabular}


Table 8. Distribution of conceptual and empirical papers

\begin{tabular}{|l|l|l|l|l|}
\hline $\begin{array}{l}\text { Conceptual } \\
\text { papers }\end{array}$ & $\begin{array}{l}\text { Empirical } \\
\text { papers }\end{array}$ & $\begin{array}{l}\text { Quantitative } \\
\text { methods }\end{array}$ & $\begin{array}{l}\text { Qualitative } \\
\text { methods }\end{array}$ & $\begin{array}{l}\text { Mixed } \\
\text { methods }\end{array}$ \\
\hline 19 papers & 63 papers & 27 & 27 & 9 \\
\hline
\end{tabular}


Table 9. Peer-reviewed articles by scales and measurements.

\begin{tabular}{|c|c|c|}
\hline No. & Scales and measurements & Frequency \\
\hline 1 & Satisfaction with Life Scale (SWLS) & 10 \\
\hline 2 & Positive and Negative Affect Scale (PANAS) & 3 \\
\hline 3 & Kahle's LOV scale & 2 \\
\hline 4 & Challenge, skill, affect and self-affirmation scale & 2 \\
\hline 5 & Modified Differential Emotions Scale (mDES) & 2 \\
\hline 6 & Recovery experience scale & 2 \\
\hline 7 & Subjective happiness scale & 2 \\
\hline 8 & Subjective well-being scale & 1 \\
\hline 9 & Recreation involvement scale & 1 \\
\hline 10 & Plutchik (1991) framework of basic emotions & 1 \\
\hline 11 & Job content questionnaire & 1 \\
\hline 12 & Travel motives scale & 1 \\
\hline 13 & Savouring beliefs inventory & 1 \\
\hline 14 & Authentic Happiness Index & 1 \\
\hline 15 & Health and well-being scale & 1 \\
\hline 16 & Quality of Life measure & 1 \\
\hline 17 & Hedonic level of affect scale & 1 \\
\hline 18 & Character strengths scale & 1 \\
\hline 19 & Novelty seeking & 1 \\
\hline 20 & Travel benefits & 1 \\
\hline 21 & Skill, challenge and playfulness & 1 \\
\hline 22 & Positive emotions & 1 \\
\hline 23 & Utilitarian shopping orientation & 1 \\
\hline 24 & Experiential shopping orientation & 1 \\
\hline 25 & Utilitarian shopping features & 1 \\
\hline 26 & Experiential shopping features & 1 \\
\hline 27 & Cognitive enjoyment and attitude & 1 \\
\hline 28 & Satisfaction and loyalty & 1 \\
\hline \multirow[t]{2}{*}{29} & Travel behaviour scale & 1 \\
\hline & Total & 45 \\
\hline
\end{tabular}


Table 10. Characteristics of research samples

\begin{tabular}{|l|l|}
\hline Characteristics of samples & No. of respondents \\
\hline Gender & \\
\hline Female & 7848 \\
\hline Male & 7459 \\
\hline & \\
\hline Age & \\
\hline Under 18 years & 197 \\
\hline 18-35 years & 4067 \\
\hline 36-55 years & 8172 \\
\hline Over 60 years & 1240 \\
\hline
\end{tabular}


Figure 1. Aims of study

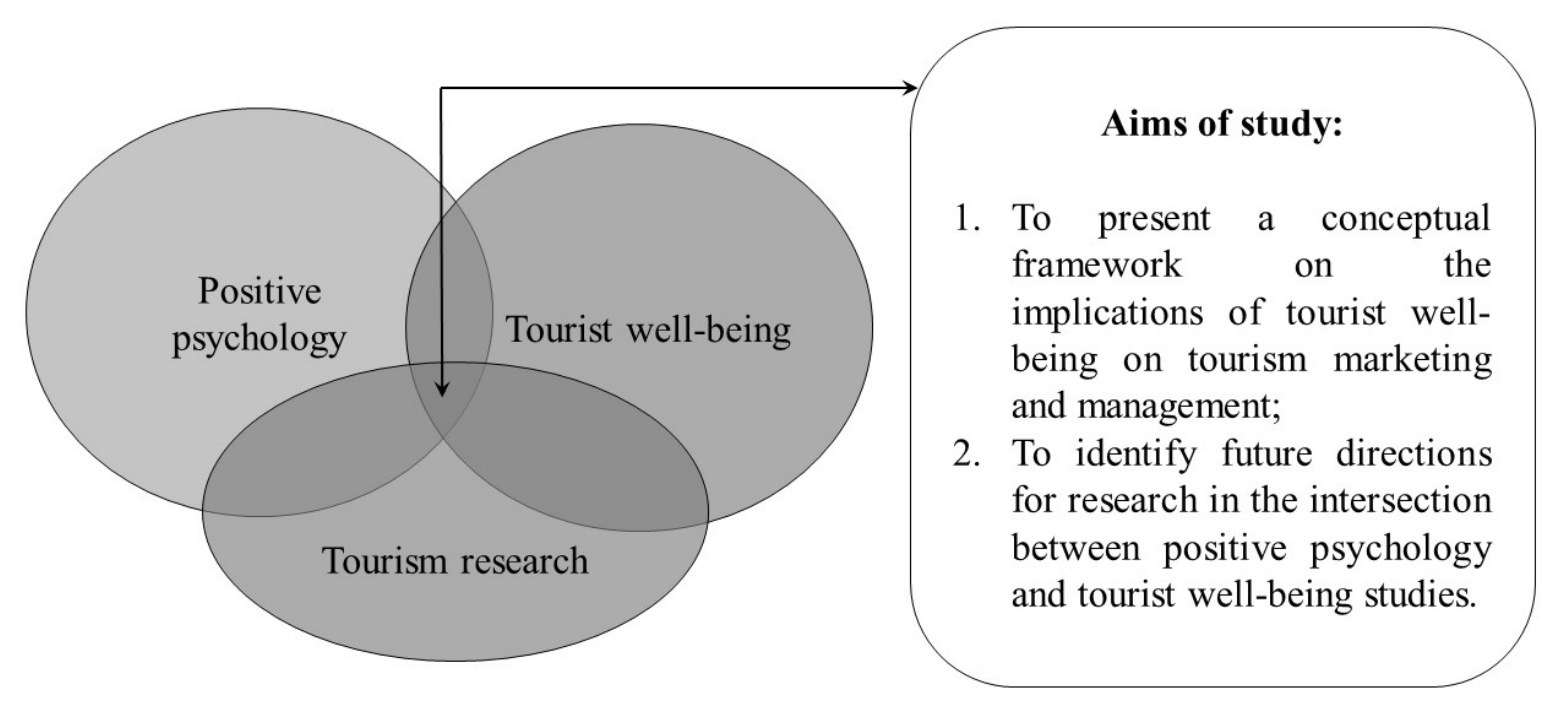


Figure 2. Summary of systematic review process.

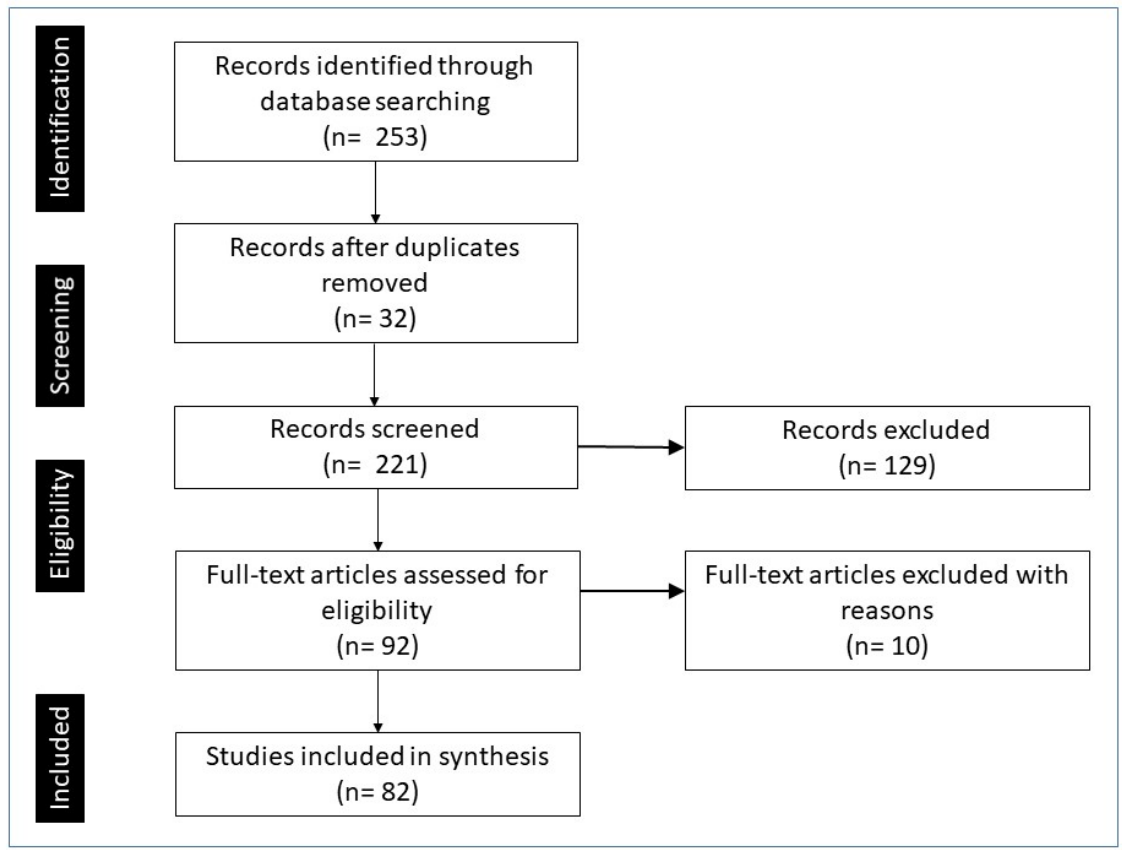


Figure 3. Cumulative frequency of peer-reviewed articles by year published

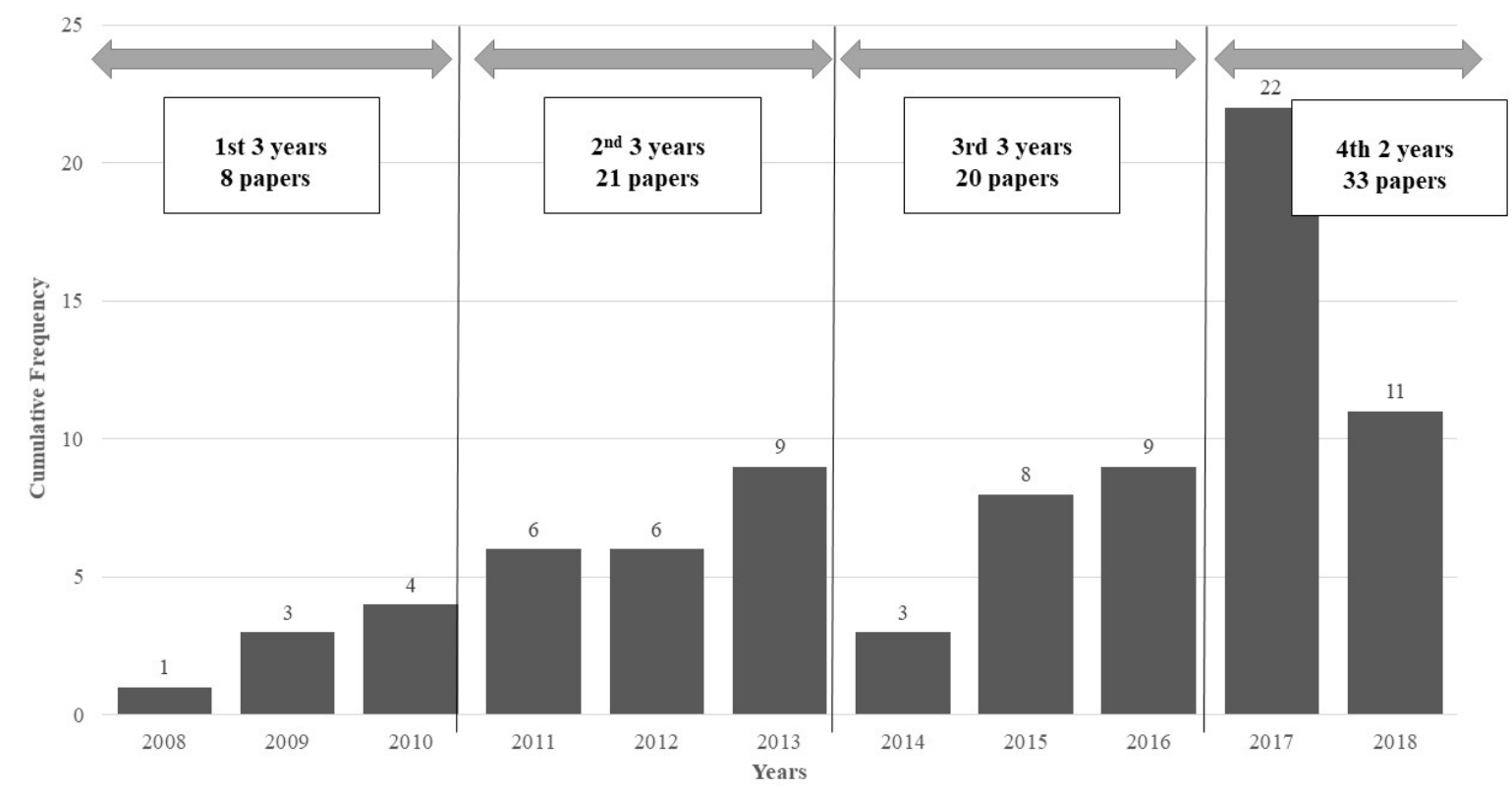


Figure 4. Peer-reviewed articles by research method

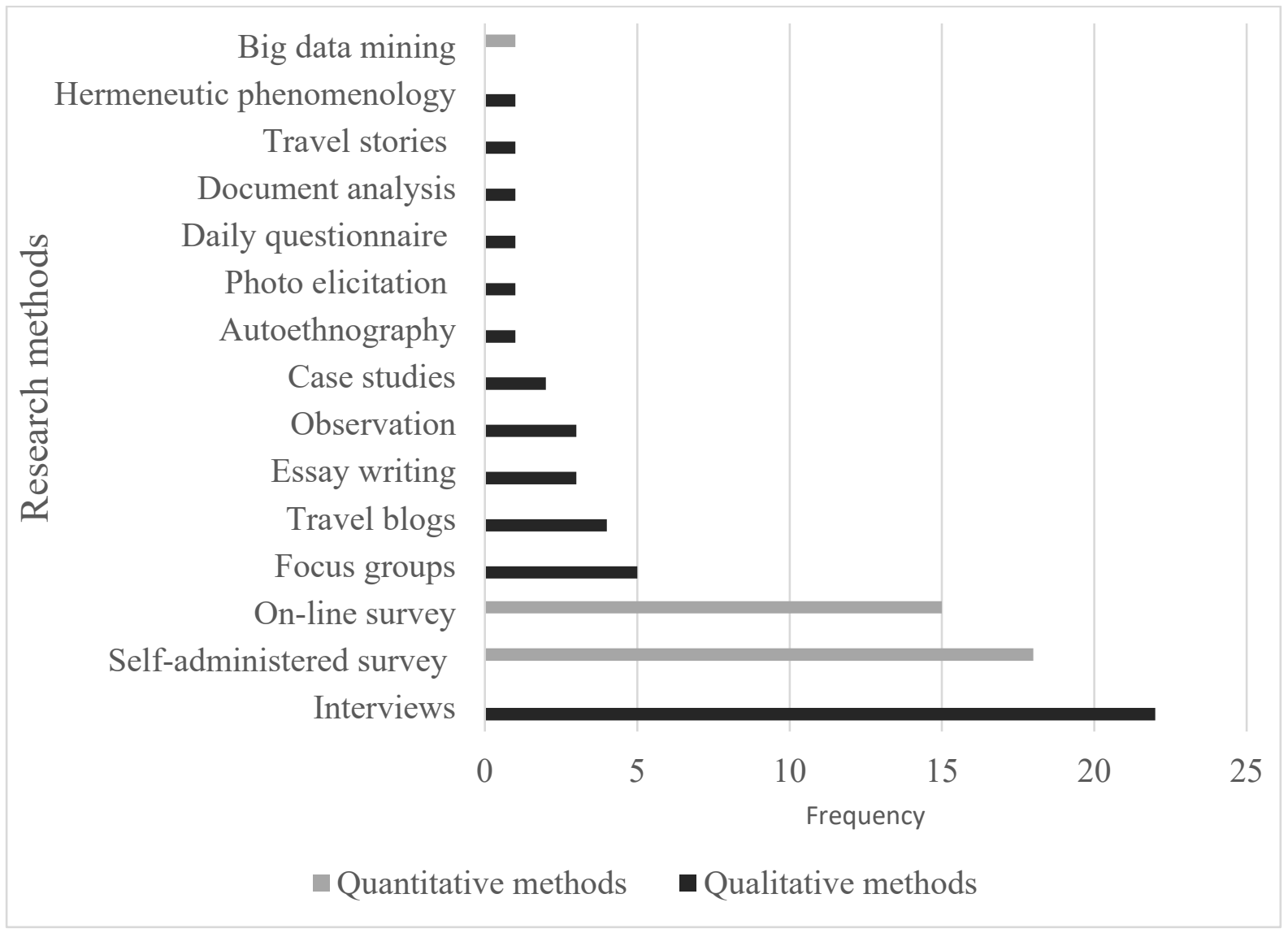


Figure 5. Peer-reviewed articles by data analysis techniques

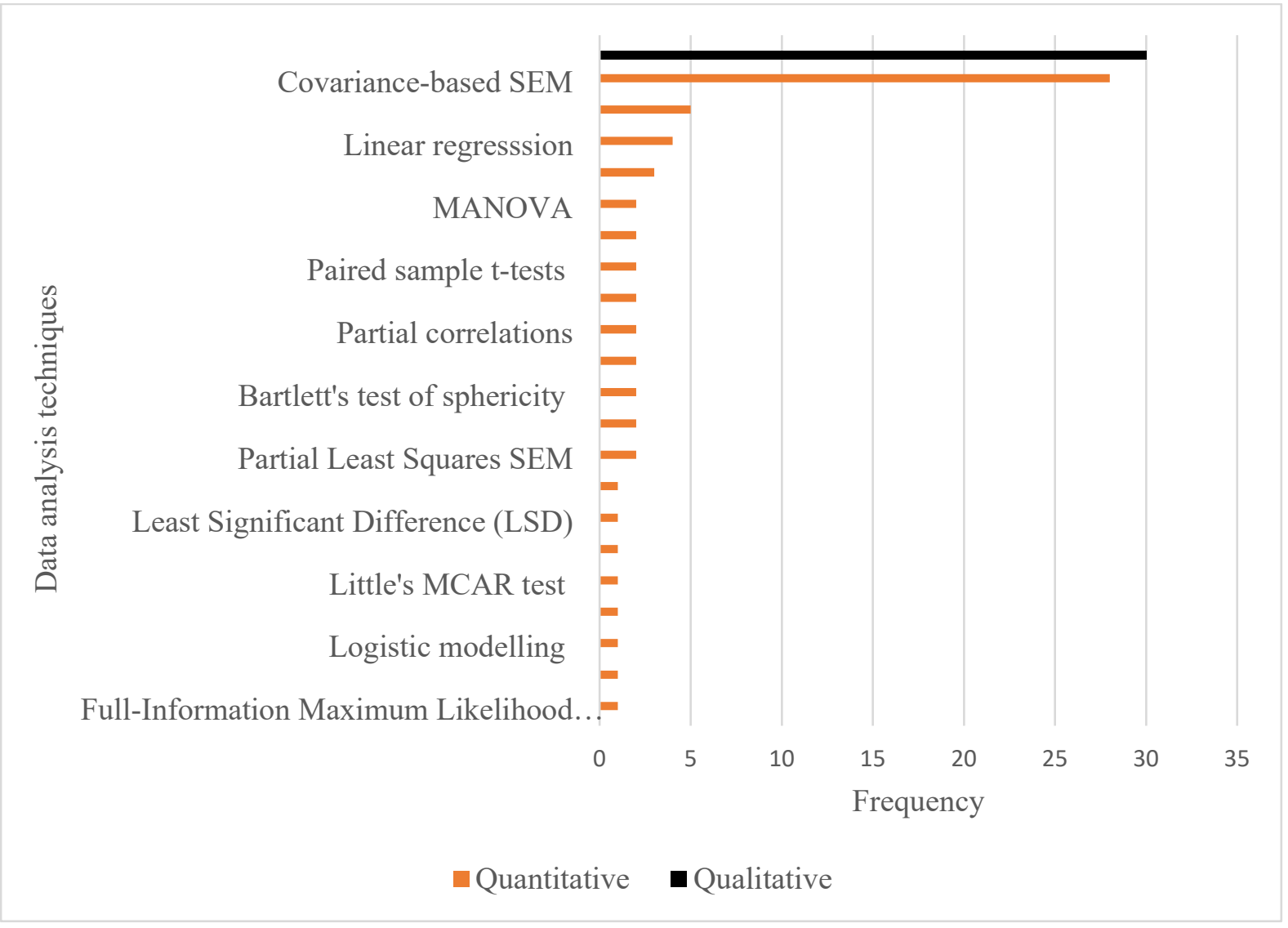


Figure 6. Location of research samples

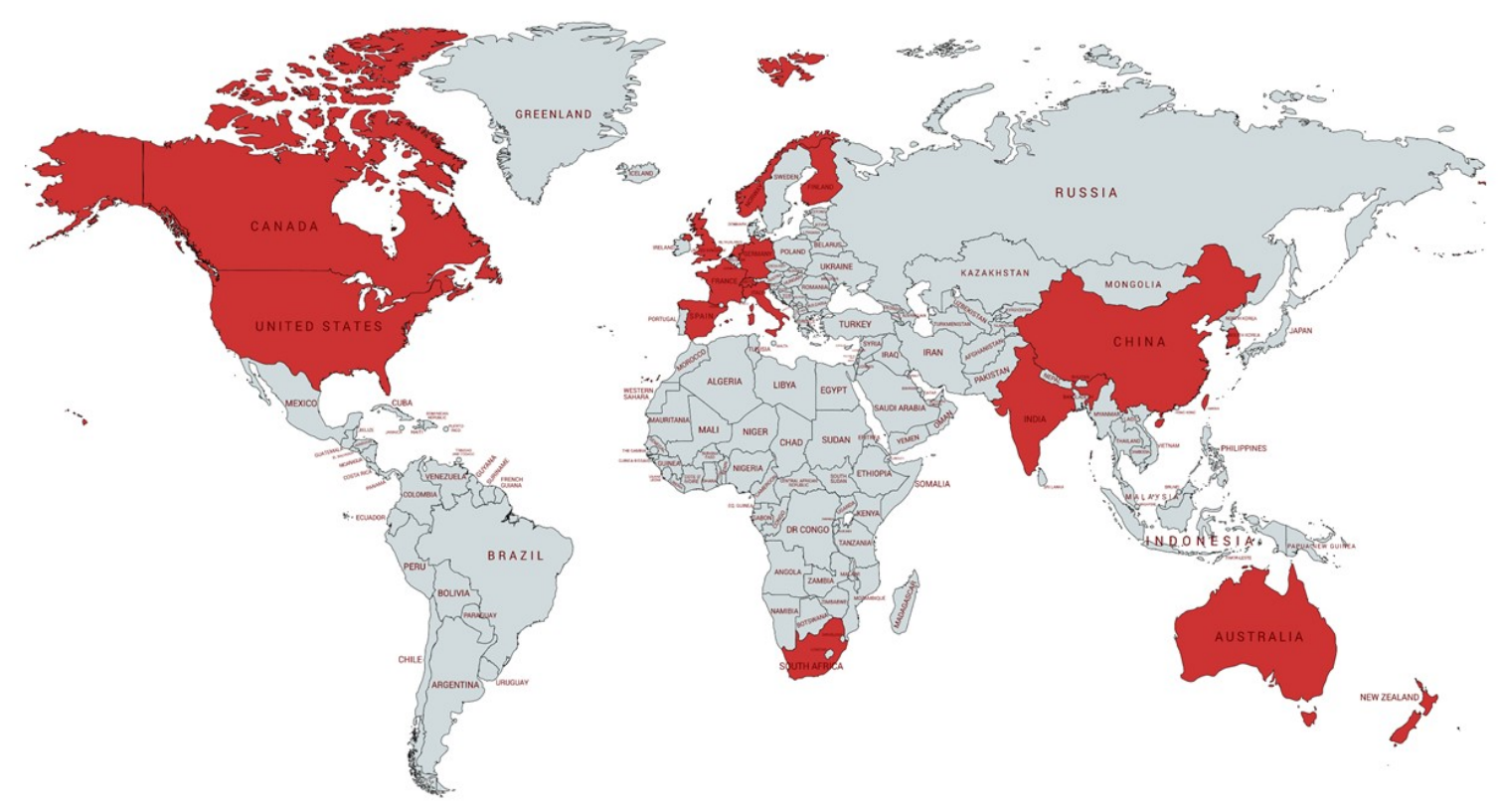


Figure 7. Mapping existing literature and future research on positive psychology and tourist well-being studies

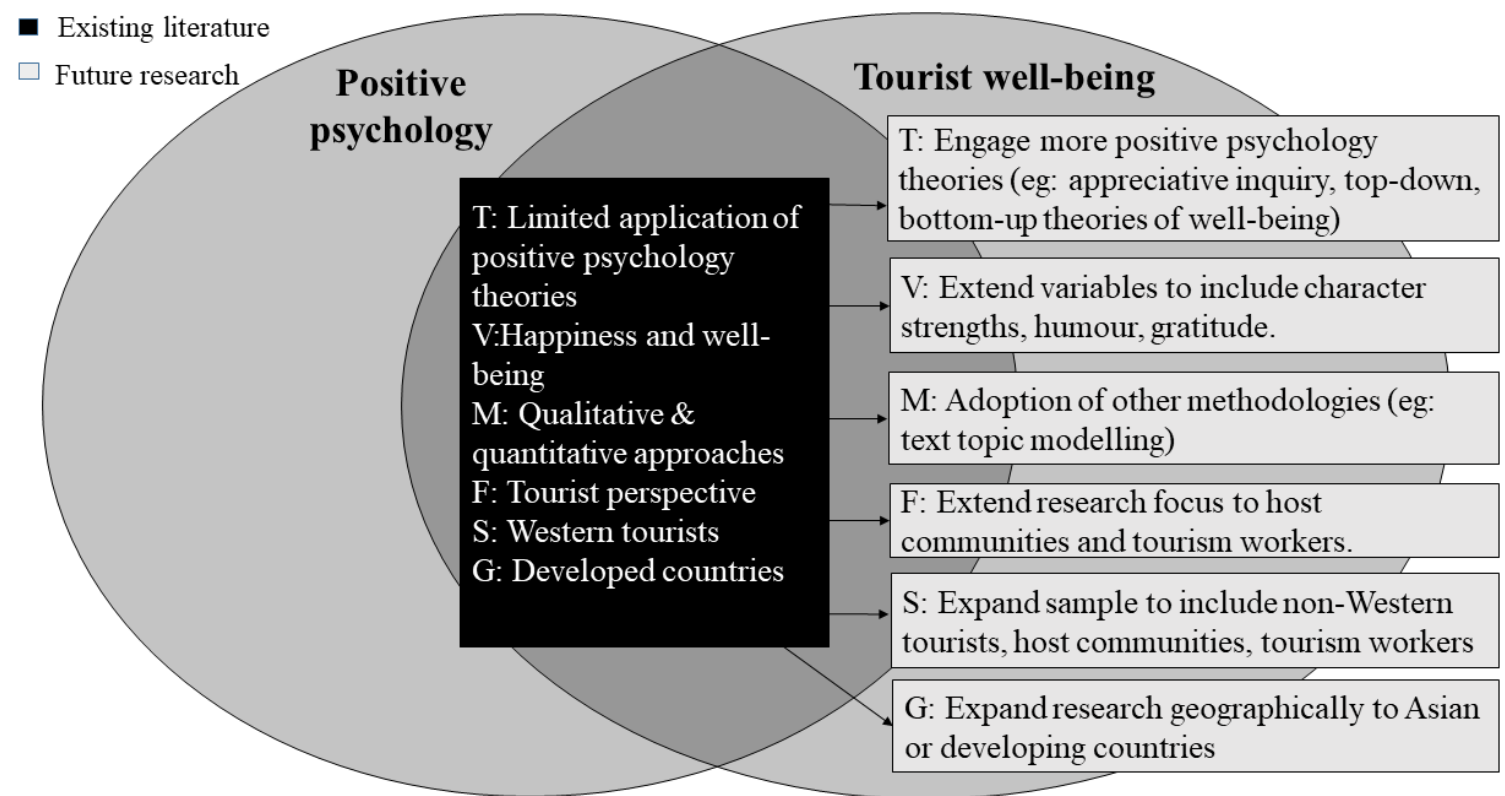

T: Theoretical frameworks; V: Variables; F: Focus of research; M: Methodology; S: Sample; G: Geographical focus 
Figure 8. Conceptual framework of tourist well-being in tourism research

\begin{tabular}{|c|c|c|}
\hline $\begin{array}{c}\text { Antecedents } \\
\text { Triggers of tourist well-being }\end{array}$ & $\begin{array}{c}\text { Episodes } \\
\text { Consumption contexts of } \\
\text { touristwell-being }\end{array}$ & \multirow[b]{2}{*}{\begin{tabular}{|c|} 
Consequences \\
Benefits for tourism \\
marketing \& management
\end{tabular}} \\
\hline \multirow{4}{*}{$\begin{array}{l}\text { Variables } \\
\text { - Happiness } \\
\text { - Positive emotions } \\
\text { - Savouring } \\
\text { - Character strengths } \\
\text { - Gratitude } \\
\text { - Humour } \\
\text { - Mindfulness } \\
\text { - Engagement } \\
\text { - Relationships } \\
\text { - Meaning } \\
\text { - Accomplishment }\end{array}$} & \multirow{3}{*}{$\begin{array}{l}\text { - Natural environment and built } \\
\text { environment } \\
\text { - Presence of silence } \\
\text { - Social environment } \\
\text { - Acts of kindness } \\
\text { - Tourist experiences } \\
\text { - Wellness tourism } \\
\text { - Yoga tourism } \\
\text { - Volunteer tourism } \\
\text { - Countries } \\
\text { - Western countries }\end{array}$} & \\
\hline & & \multirow{4}{*}{$\begin{array}{l}\text { - Revisit intentions } \\
\text { - } \text { Positive word-of-mouth } \\
\text { in value co-creation } \\
\text { with tourists } \\
\text { - } \text { Positive attitudes } \\
\text { towards poverty } \\
\text { alleviation and } \\
\text { development issues }\end{array}$} \\
\hline & & \\
\hline & \multirow[b]{2}{*}{$\begin{array}{l}\text { Promotes tourist health and well-being } \\
\text { - Positive aging through social } \\
\text { support } \\
\text { - Belongingness to social world } \\
\text { - Finding one's inner self } \\
\text { - Ability to cope with the stresses of } \\
\text { life }\end{array}$} & \\
\hline $\begin{array}{l}\text { Positive psychology } \\
\text { theories } \\
\text { - Broaden and build theory } \\
\text { - Flow theory } \\
\text { - PERMA model } \\
\text { - Mindfulness theory }\end{array}$ & & \\
\hline
\end{tabular}

